\title{
Plotinus on Happiness
}

\author{
Lloyd P. Gerson (University of Toronto)
}

This paper explores Plotinus' criticism of Aristotle and the Stoics on happiness, and his own Platonic alternative account. It also seeks to show how Plotinus has appropriated elements of his opponents' own views. For Plotinus, happiness is a sort of self-transformation in which one identifies with one's ideal intellectual self. The achievement of such an identification brings together, as for the Stoics and Epicureans, happiness and blessedness, although for Plotinus, blessedness is real immortality.

\section{Introduction}

Let us begin like Plotinus himself with Aristotle's account of happiness. Aristotle claims in Book 1 of his Nicomachean Ethics that the human end is happiness (eudaimonia) and that happiness is virtuous activity. By 'end' Aristotle means 'goal' or 'purpose'; everything human beings do, they do for happiness. Thus, happiness, if achieved, is 'complete' or 'perfect' and 'self-sufficient'. What this means, at least, is that if a person is happy, then the virtuous activity which comprises his happiness has no ulterior motive. For example, being a courageous person, doing courageous deeds as called for, has no explanation or justification other than that is what happy people are and what happy people do.

There are at least two major problems with this account. The first is that Aristotle just assumes that there is such a thing as 'the' human end. One might object that in fact there are as many human ends as there are human beings. True, Aristotle does offer an argument- the socalled function (ergon) argument-for the claim that there is a human end that belongs to the 
Journal of Ancient Philosophy Vol. VI 2012 Issue 1

species as such. ${ }^{1}$ The argument is biological in nature. Since all the organs of a human being manifestly possess a function, it would be reasonable to conclude that the human being has a function. But this function cannot be one over and above the function of the organs, for so to suppose would be to commit the grossest fallacy of composition. That function must be identical with the function that all the organs serve, namely, the continued living of the human being. And since living and living well are, so to speak, functionally identical, we can conclude that the function of a human being is living well. Yet 'living well' can be said to be the function of all animals and even plants. So, when we talk about living well for a human being, we must specify what is distinctive about a human being. That, says Aristotle, is rational activity. I shall have much more to say about rationality below. For now, though, let us accept that the good for human beings is rational activity. If one lives a life of rational activity, in the way that Aristotle specifies 'rational activity' with all its moral and intellectual parts, then one is happy. This leads to the second problem.

That there is one ultimate end or goal for humankind has little or no relevance to individual human beings and their plans for living unless they can be brought around to wanting that end. But Aristotle says that all human beings want that end because all human beings want happiness and that end is identical with happiness. Here is our second problem. What if living a life of rational activity does not make me happy? One immediate response would be to say that when Aristotle speaks about 'happiness', he is not referring to the subjective feeling that one has when one says 'I am not happy'. Whether you feel happy or not is irrelevant to whether or not you are fulfilling the human function. This may indeed be so. But then why would one want to fulfill that function if it does not make one subjectively happy? Conversely, if the subjective feeling is what we are after, why focus on the function that is specifiable only generally? Is it not preposterous to maintain that the rational agent who on reflection believes that he is unhappy ought to persevere knowing that he is in fact happy after all because he is fulfilling the human function? To put the problem slightly differently, if fulfilling the human function is something that all human beings do insofar as they live human lives (what after all is the alternative?), then

\footnotetext{
${ }^{1}$ Nicomachean Ethics 1.6.1097b22-1098a20.
} 
Journal of Ancient Philosophy Vol. VI 2012 Issue 1

why suppose that non-virtuous activity is any less function-fulfilling that virtuous activity? It will do no good to reply that virtue is just excellence, and no one wants to be a mediocre $\mathrm{x}$ as opposed to an excellent x. In fact, many people are quite happy to be mediocre, and many others will rightly insist that what is counted mediocre in one context is counted excellent in another, especially if the mediocrity is accompanied by a subjective feeling of happiness.

Aristotle does not sever 'objective' happiness from 'subjective' happiness completely. He holds that if you are objectively happy, that is, if you act virtuously as the virtuous person acts, then you will have the best possible chance of being subjectively happy, too. The objectively happy life is a satisfying life, but only for the person who really is virtuous. This claim invites the obvious objection that one may prefer to achieve a satisfying life other than by pursuing virtue, say, because of its rigorous requirements. Unless Aristotle can show, against all plausibility, that only the virtuous life is satisfying, he needs to show why one should prefer to commit oneself to virtue as a means of satisfaction rather than anything else. Aristotle is deeply aware of this problem and he repeatedly alludes to it in Book 1, although most commentators pass over the allusions. Aristotle distinguishes between 'happy' and 'blessed' (makarios). The latter is primarily a characteristic of the gods. ${ }^{2}$ The gods are blessed because they are immortal. Their immortality makes them impervious to the misfortunes and continual aggravations that threaten human life. A god may become irritated, but he is sure to get over it. Human beings are, so long as they live, faced with the possibility of tragedy. So, though a human being may be happy in Aristotle's sense, he cannot thereby be counted blessed. A happy man will indeed possess a prophylactic against disaster, because he can draw on his inner virtuous resources to get him through trouble. But he will not be blessed if he should meet with the fortunes of Priam. ${ }^{3}$ If he is happy and if he manages to avoid personal tragedy, then we will call him 'blessed', that is, blessed only in the secondary qualified way that befits a mortal.

Being happy is one thing, according to Aristotle, and being blessed- living a charmed life, we might say - is another. The former is within one's control and the latter is not. Since the

\footnotetext{
${ }^{2}$ Cf. Homer, Odyssey 10.299.

${ }^{3} N E$ 1.10.1101a6-8; cf. 1.9.1099b2.
} 
Journal of Ancient Philosophy Vol. VI 2012 Issue 1

latter is not within our control, we cannot aim for it as the good we seek. On the other hand, we can aim for the ultimate good which is happiness, and if we achieve that, we thereby limit the extent to which ill fortune can affect us. ${ }^{4}$ Aristotle's eminently reasonable acknowledgement that ill fortune can affect even the happy person reveals the problem. Let us put it paradoxically: $\mathrm{S}$ is happy because he lives a life of virtuous activity, a life furnished with sufficient external goods to enable that activity. But $\mathrm{S}$ is at the same time unhappy because he is currently suffering a dreadful reversal of fortune. Think of Job. How can this be? We may facilely reply that $S$ is happy in one sense, but unhappy in another, thereby supposedly eliminating the paradox. This distinction does nothing to solve the problem of why the sense in which $\mathrm{S}$ is happy is to be privileged over the sense in which $S$ is unhappy. Consider the opposite case: $S$ is unhappy in Aristotle's sense, but has lived a charmed life. If in response to such a case we wish to say 'too bad for S', to whom are we really speaking? The point is not that happiness is in our control but the unhappiness of ill fortune is not. Rather, the point is that if we want the happiness of good fortune more than the happiness of virtuous living, then, though of course there are things out of our control, still we can focus on or aim for the former, that is, aim for the state of one who, paradigmatically, lives a charmed life.

It hardly seems helpful to insist that in fact the happy life is the most pleasant for the virtuous man. ${ }^{5}$ Either this pleasure is the goal, in which case it needs to be compared with the pleasure of the non-virtuous life by the non-virtuous person, or else it is not the goal, in which case the question remains as to why virtue is supposed to bring happiness in the sense in which anyone wants it. Stated otherwise, either 'happy' just means 'virtuous' in which case the question remains as to why one ought to be virtuous, or else 'happy' means something more, including the feeling which is supposedly the opposite of the feeling one has in the face of extreme misfortune. And in that case, what is the non-subjective criterion for adjudicating between the desirability of Aristotelian happiness and the happiness of the anti-Job, the nonvirtuous man who lived a charmed life?

\footnotetext{
${ }^{4}$ Cf. $N E 1.10 .1100 \mathrm{~b} 22-33$.

${ }^{5} N E$ 1.9.1099a11-21.
} 
It is only a small exaggeration to say that the essence of Hellenistic ethics is contained within the response to this problem.

Epicurus straightforwardly identifies 'happy' with 'blessed' ${ }^{6}$ So, there is no possibility that one should be happy and 'unhappy' or wretched at the same time. He does this by claiming, in effect, that 'happy' and 'blessed' are two different names for one state, that of an 'absence of disturbance' (ataraxia). ${ }^{7}$ Against the obvious objection that this cannot be so because the divine nature is blessed owing to its immortality, Epicurus famously argues that 'death is nothing to us'. If the gods are blessed just because they need not fear death, then if we, too, need not fear death, we can be blessed as well. The operative words here are 'can be' not 'are'. The very fact that we are convinced that death is nothing to us does not thereby make us blessed or happy. Yet, when this conviction does seize us, we immediately realize that being blessed or happy consists entirely in being in a state that is satisfying and that this state is not difficult to attain. It is a state in which all pain is removed. ${ }^{9}$ It is a state of complete absence of disturbance. Regarding the Aristotelian willingness to distinguish happiness and blessedness and thereby to allow the distinction between objective and subjective 'happiness', the denial of the former distinction entails the denial of the latter. To claim that there can be a Job, pained at his ill fortune yet happy in the Aristotelian sense is, for Epicurus, to make a sort of category mistake. For this happiness is just irrelevant to blessedness or, more to the point, that which all human beings desire. But we recall that, though Aristotle distinguishes happiness and blessedness, he does not think that they are completely unconnected. The completely happy Aristotelian man is as blessed or as close to being blessed as a human being can be.

Epicurus does not maintain that virtue is irrelevant to the blessed state of satisfaction: "we choose virtues, too, for the sake of pleasure and not for their own sake' ${ }^{10}$ The claim that virtue is instrumental to happiness is likely to be an empirical one, but whatever its epistemological

\footnotetext{
${ }^{6}$ Diogenes Laertius, Lives and Opinions of the Philosophers (D. L.), 10.128; cf. 122.

${ }^{7}$ D. L., 10.78; cf. Cicero, de natura Deorum 1.53.

${ }^{8}$ D. L, 10.124-6.

${ }^{9}$ D. L., 10.128; cf. Cicero, de finibus 1.38.

${ }^{10}$ D. L., $10.138 ;$ cf. $140=$ Principal Doctrines 5.
} 
Journal of Ancient Philosophy Vol. VI 2012 Issue 1

status, it indicates that Epicurus refuses to consider the life of virtue and the life of pleasure as alternatives, the commensuration of which makes any sense at all. He refuses to countenance the possibility that one could rationally conceive of happiness and blessedness as real alternative goals, opting for the former in the hopes that he will thereby come as close as possible to the latter.

Although our evidence is fairly slight, the Old Stoa also seems to reject any distinction between happiness and blessedness ${ }^{11}$ Again, as in Epicurus, the rationale for this is the identification of happiness and blessedness with 'absence of disturbance'. ${ }^{12}$ But, unlike Epicurus, since happiness (and therefore blessedness) is constituted of virtue, virtue is chosen for its own sake. ${ }^{13}$ And so like Epicurus, there is no possibility for rational opposition between virtue and happiness, if happiness is taken subjectively. The sense in which the Stoics make this claim is best seen in their view that things normally indicated as constituting subjective happinesshealth, pleasure, beauty-are in fact 'indifferents' (adiaphora). ${ }^{14}$ It is possible to be happy without these. ${ }^{15}$ Conversely, one cannot be happy if one is not virtuous. ${ }^{16}$

In the face of such an extreme view, one might suppose that the Stoics have merely redefined 'happiness' to exclude the subjective altogether. If this is what they have done, then the simple and obvious reply that the anti-Stoic might want to make is that he has no desire to be 'objectively' happy; his subjective state of 'unhappiness' is preferable, thank you very much. Surely, what the Stoics need is an argument designed to show that objective Stoic happinessthe virtuous life-is the life that anyone would choose if we were fairly apprised of the contents,

\footnotetext{
${ }^{11}$ Stobaeus, Eclogues 2.11g, p.99, 3 Wachsmuth-Hense = Stoicorum Veterum Fragmenta (SVF) 1.216; cf. Sextus Empiricus, Adversus Mathematicos $7.12=$ SVF 1.356; Alexander Aphrodisias, de anima mantissa p. 168,1 Bruns $=S V F 3.766$.

${ }^{12} \mathrm{Cf}$. Seneca, Epistles 92.3: securitas et perpetua tranquilitas.

${ }^{13}$ D. L., $7.89=S V F 3.39$.

${ }^{14}$ D. L., 7.101-3. The distinction between preferred and dispreferred indifferents. Stobaeus, Eclogues 2. 7d, p.7 9, 18ff Wachsmuth-Hense $=S V F 3.133,140$.

${ }^{15}$ D. L., $7.104=$ SVF 3.104.

${ }^{16}$ Plutarch, de Stoicorum repugnantiis $1042 \mathrm{~A}=$ SVF 3.55; cf. SVF 3.585, where the Stoics are reputed to have insisted, presumably, against Aristotle or other Peripaetetics, that it is indeed possible to be happy inside the bull of Phalaris.
} 
Journal of Ancient Philosophy Vol. VI 2012 Issue 1

so to speak, of that life, from the inside. If, however, being apprised of the contents of the virtuous life from the inside requires that one be virtuous, then the sought for Stoic argument would only show, in effect, that virtuous people prefer being virtuous. To insist, as the Stoics do, that all non-virtuous people are mad is not likely to count as a telling point against those who are satisfied to live the putative madness of the dissolute life.

On behalf of the Stoics, it seems fair to point out that the circularity of the claim that only the virtuous can testify to the superiority of the virtuous life is not a vicious circularity. Why should someone who is not virtuous be supposed to understand this, and why is his lack of understanding supposed to undermine the Stoic argument? Nevertheless, the claim for the objective superiority of the virtuous life is going to have force only for someone who agrees on the identification of happiness and blessedness, whether this identification is effected by their identification with 'absence of disturbance' or not. Is there any way out of this impasse?

The Stoic approach is to hearken back to Socrates. ${ }^{17}$ Their insistence on the sufficiency of virtue for happiness is equivalent to the Socratic absolutist prohibition of wrongdoing. ${ }^{18}$ According to Socrates, wrongdoing inevitably and necessarily harms the soul of a person. But Socrates' detractors and opponents will want to insist that 'soul care' probably has a downside as well as an upside. And in weighing the pros and cons of soul care, one should not fail to consider the pros and cons of body care, too. So, the exhortation to avoid wrongdoing, taken as equivalent to an exhortation to essential soul care, needs to be qualified. A sober cost-benefits analysis will sometimes indicate the privileging of soul care over body care and sometimes it will do the opposite. But that is exactly what the anti-Stoic wants to claim. One in pursuit of the happy life must engage in such calculation and eschew the rigorous approach of a Socrates or of his Stoic disciples.

The Socratic response in brief is that the soul is identical with the self, and the neglect of soul care is equivalent to self destruction. ${ }^{19}$ Wrongdoing is presumably the antithesis of soul

\footnotetext{
${ }^{17}$ The Socrates of the dialogues, who in my view is not distinguishable from Plato. But that is a topic for another paper.

${ }^{18}$ See Crito 49B8: 'One must never do wrong'; cf. 49A6-7, Apology 29B6-7; Gorgias 469B12, 508E, etc.

${ }^{19}$ See Gerson (1996), 7-10.
} 
care. A wrongdoer can no more hope to benefit from his wrongdoing than one can hope to preside over one's own funeral. Why exactly wrongdoing should lead to self destruction is nowhere explicitly explained in Plato's dialogues. However, Plato's remarks on personhood, especially in Republic and Timaeus, do indicate the direction of an answer, and it is this direction that the Stoics and Plotinus will eventually follow.

The Socratic identification of the soul with the self is sophisticated by Plato's tripartition of the soul and his subsequent designation of the rational part as the true self, the 'human being within the human being, ${ }^{20}$ It is somewhat misleading to speak of the rational part if this suggests that reason or rationality is not involved in the operation of the other two parts of the soul, the appetitive and the spirited. Thus, the embodied person who acts to satisfy an appetite is not acting independent of his reason, for reason is deployed both in conceptualizing the object of desire and in calculations made on how to achieve it. The identification of the person with the rational part of the soul is the identification of the person with the subject of embodied human action, all of which is rational in the above sense. But reason, and hence, the self or subject, is present both as the subject of a desire and as the subject that endorses or fails to endorse the desire that it has itself. ${ }^{21}$ The rational subject is essentially self-reflexive in this way. So, to address questions about the satisfaction or happiness of the self and self destruction, one must consider how rationality thus construed is exercised and how it is destroyed.

Crucially, Plato argues for a disembodied rational self, identified with the immortal part of the soul. ${ }^{22}$ This disembodied self evidently desires nothing that requires a body; it has no bodily appetites, for example. Yet, it is no doubt continuous with the embodied self. If it were not, post-mortem rewards and punishments would be meaningless, to say nothing of reincarnation. So, we must suppose that the embodied person is a sort of image of its disembodied exemplar. I would argue that this is so in exactly the way that instances of Plato's Forms are images of these Forms, but that is not the central point here. ${ }^{23}$ That point is that if I

\footnotetext{
${ }^{20}$ Alcibiades I 130E8-9; Republic 589A7-B1.

${ }^{21}$ Failing to endorse it in the prerequisite for incontinence or akrasia.

${ }^{22}$ Timaeus 90C.

${ }^{23}$ See Gerson (2003), chs. 3 and 6.
} 
make a commitment to pursuing what 'I' really want—objective or subjective happiness—-then I must be in a position to identify that 'I'. And the identification in a Platonic context is not so straightforward, since I can identify it either as the embodied 'I' or the disembodied 'I', the former being merely an image of the latter.

The ambiguity imported into ethical calculation by the distinction between an ideal and its image is not uniquely Platonic in origin. Consider, as the Stoics do, for instance, the person who has to choose between present satisfaction and future well-being. The choice between what the present 'I' wants and what the present 'I' thinks the future 'I' will want is exactly analogous to the choice between what the subject qua image wants and what the subject qua image thinks the ideal subject wants. This is so even if in the former case the future 'I' is bound to become a present 'I' with another future 'I' to consider. Now just as a claim about what 'I' want now might be challenged (whether by oneself or by another) by a comparison with what 'I' will want in the future, so the choices of the subject qua image might be challenged by a comparison with the ideal self. The point of course is that the challenger does not have to say things like, "you ought to want something different for yourself' but rather either 'you will want something different for yourself' or, more radically in the case of the ideal self, 'you do want something different for yourself'. A youth does not have to be convinced that he does not now want what he wants; he only (!) needs to be convinced that when he grows up he will want something else and that his present pursuits will make that impossible or at least unlikely. The argument for privileging the future person over the present is in part that one is likely to spend a much longer time as an adult than as a youth. How much stronger would this argument be if the two poles of comparison were a mortal embodied self and an immortal disembodied self?

The Stoic exhortation to 'live in agreement with nature' is the basis of their interpretation of the Socratic-Platonic account of the self. ${ }^{24}$ In one sense, a human being cannot fail to live in agreement with nature. That is the sense in which he is an embodied subject of rational activity. But in another sense, a human being can and typically does fail to live in agreement with nature, when living in agreement is taken to be an ideal. For the Stoics, the ideal is not a disembodied

${ }^{24}$ D. L., 7.87 = SVF 3.4; Stobaeus, Eclogues 2.7, 6a, p.76, 3 Wachsmuth-Hense = SVF 1.55 .2 
Journal of Ancient Philosophy Vol. VI 2012 Issue 1

one; nevertheless, it is an ideal wherein the subject is identified with the rule of reason or with Zeus himself. $^{25}$ It is to be emphasized that the Stoics thus import normativity into the fabric of nature. The ideal is as natural as an endowment. And the Platonic identification of the endowment with a counterfeit or image is no less censorious than is the Stoic description as mad anyone who lives a life according to the endowment and not according to the ideal.

It may be worth noting as we proceed to Plotinus that the Socratic-Platonic-Stoic view is not at all rejected by Aristotle himself. In his remarks concerning the best life at the end of his Nicomachean Ethics, he says,

Such a life would be above that of a human being, for a human being will live in this manner not insofar as he is a human being, but insofar as he has something divine in him; and the activity of this divine part of the soul is as much superior to that of the other kind of virtue as that divine part is superior to the composite soul of a human being. So, since the intellect is divine relative to a human being, the life according to this intellect, too, will be divine relative to human life. Thus we should not follow the recommendation of thinkers who say that those who are human beings should think only of human things and that mortals should think only of mortal things, but we should try as far as possible to partake of immortality and to make every effort to live according to the best part of the soul in us; for even if this part be of small measure, it surpasses all the others by far in power and worth. It would seem, too, that each man is this part, if indeed this is the dominant part and is better than the other parts; so it would be strange if a human being did not choose the life proper to himself but that proper to another. And what was stated earlier is appropriate here also: that which is by nature proper to each thing is the best and most pleasant for that thing. So for a human being, too, the life according to his intellect is the best and most pleasant, if indeed a human being in the highest sense is his intellect. Hence, this life, too, is the happiest. $^{26}$

This remarkable passage, so frequently discounted in the literature, explicitly acknowledges first that 'a human being in the highest sense is his intellect'. So, the life according to the intellect (whatever that means) is the happiest life for a human being. But this life is 'above that of a human being'; it is a divine life compared with a human one. The divine life is the ideal. It is that life which is unqualifiedly blessed. It is that life which is most pleasant, but only for one who acknowledges that it is his own ideal life. One who prefers satisfaction to virtue or blessedness to happiness as construed by Aristotle is not completely wrong because he is implicitly acknowledging the distinction between the divine ideal and the human endowment.

\footnotetext{
${ }^{25}$ D. L., $7.88=S V F 1.162$.

${ }^{26}$ EN 10.7.1177b26-1178a8. Cf. 9.4.1166a22-3, 9.8.1168b31-3. Cf. Protrepticus B62, 85-6.
} 
Journal of Ancient Philosophy Vol. VI 2012 Issue 1

And in this acknowledgment in the starting point for a substantive dispute over the nature of that ideal as opposed to a mere conflict of incommensurable subjective valuations.

\section{Plotinus}

Plotinus' Platonism is woven out of two strands: (1) the effort to construct a consistent and comprehensive philosophical vision out of a reading of the dialogues supplemented by oral and written testimony, especially that of Aristotle; (2) the effort to defend the vision thus constructed against what Plotinus perceives to be attacks on it. Plotinus can thus take as 'Platonic' claims that Plato does not explicitly make but that he could or would make in response to criticisms and based on the vision revealed in (1). For our focus on Plotinus' account of happiness, the fundamental opposition Plotinus is concerned with comes from various forms of materialism. A materialist, according to Plotinus, who follows Aristotle in this regard, must hold that there are no other entities than those that exist by nature. So, they would in effect maintain that physics is first philosophy. ${ }^{27}$ For this reason, they would reject the hierarchical Platonic metaphysics wherein primary being is immaterial. ${ }^{28}$

Plotinus assumes that a defensible account of human happiness or virtue will amount to an application of general metaphysical principles. If happiness is the good for human beings, then that good must be understood as an expression or image of the primary or Absolute Good. ${ }^{29}$ It is proximity to the Absolute Good or One that provides the index of a thing's goodness,

\footnotetext{
${ }^{27}$ Cf. Metaphysics 6.1.1026a22-32.

${ }^{28}$ Aristotle was understood by Plotinus and later Platonists to accept this hierarchical metaphysics with immaterial being as primary. But the Prime Unmoved Mover was itself not the primary focus of first philosophy owing to the fact that as Primary Thinking its being is complex. For Plotinus, the Prime Unmoved Mover was Aristotle's version of the Demiurge and took second place within the hierarchy. The primary focus of first philosophy is the One or the Good.

${ }^{29}$ See Enneads 1.4.3.28-33: 'So its [the human being's] good will not be some brought in from outside, nor will the basis of its goodness come from somewhere else and bring it into a good state; for what could be added to the perfect life to make it into the best life? If anyone says, "the Absolute Good," that is our own way of talking, but at present we are not looking for the cause, but for the immanent element'. See Philebus 60B10-C4 which is perhaps the text indicating why Plotinus refers to 'our own way of talking'.
} 
Journal of Ancient Philosophy Vol. VI 2012 Issue 1

including the goodness of a human being. ${ }^{30}$ More specifically, a human life can be 'graded' according to whether it is approaching or retreating from the Good.

We have seen that Aristotle agrees with Plato in identifying the human being ideally with his or her own intellect. Not surprisingly, Plotinus assumes this to be true. ${ }^{31}$ Hence, the terminus of our identification with the Good as human beings is our identification with our intellects. In identifying the human being ideally with his intellect, Plotinus is following the Stoics as well as Plato and Aristotle. It is a slightly more complicated matter to explain how, despite this, Plotinus wishes at the same time to side with Plato against both Aristotle and the Stoics. ${ }^{32}$

As for Aristotle, the difference is best seen in the light of his rejection of an Idea of the Good. ${ }^{33}$ This rejection follows from his identification of the first principle of all with the Prime Unmoved Mover. Nevertheless, this Unmoved Mover is or has the 'highest good' in nature. ${ }^{34}$ Accordingly, the highest good for us in so far as we identify ourselves with the divine in us will just be the unimpeded intellectual activity that the Unmoved Mover engages in perpetually. For Plotinus, too, what a human being is ideally is an intellect. But in contrast to Aristotle, what makes identification with the intellect the highest human good is proximity to the Absolute Good or One. Goodness or Oneness is not identical with intellection; it is what accounts for the goodness of intellection. This difference might seem relatively insignificant, but it is what leads Aristotle to identify the highest good as that which we embodied human beings achieve intermittently when we engage in theoretical activity. And by contrast it is what leads Plotinus to

\footnotetext{
${ }^{30}$ See 4.3.6.27-34: "For we must understand that souls were called "second" and "third" according to whether they are nearer to or farther from [the intelligible world]; just as among us too not all souls have the same relationship to the realities there, but some men may unify themselves, others nearly reach this point in their striving, and others attain it in a lesser degree, in so far as they act by powers which are not the same, but some by the first, others by that which comes after it, others by the third, though all of them have all'.

${ }^{31}$ See 1.1.7.14-24, 6.7.5.1-2 which distinguishes the human being from the soul that informs the body.

${ }^{32}$ Cf. Republic 443E1 and 554D9-10 where Plato describes the virtuous person as 'becoming one out of many' which Plotinus interprets as a sort of self-unification. Cf. 1.2.6.3-7, 17-28 where Plotinus specifically mentions the state of one who has 'become one' and who in this state practices embodied virtue. So, too, 6.9.3.20-3.

${ }^{33}$ See Nicomachean Ethics 1.4 .

${ }^{34}$ See Metaphysics 12.10.1075a11ff.
} 
hold that embodied theoretical activity is only an image of the highest good. For Aristotle, the highest good is not achieved by anything like a loss of the embodied or endowed self. The human being who strives for and then achieves theoretical activity and afterwards remembers having achieved this can readily identify himself as continuous throughout this process. For Plotinus, our intellects are 'undescended' and 'unaffected'. ${ }^{35}$ This means that it is without the desire (orexis) acquired by soul in its descent. The striving that the embodied person has for Plotinus is, when it is aimed towards the Absolute Good, a striving to be reunited with a state in which there is no striving, the state that consists in permanent contemplation of the Good via cognitive identification with all that is intelligible.

Aristotle agrees that intellect is 'unaffected'. ${ }^{36}$ But in urging us to 'immortalize' ourselves by 'living according to the best part' in us he is not evidently urging the profound selftransformation implicit in Plotinus' claims. ${ }^{37}$ And that is undoubtedly because embodied intellection could only be an image of disembodied intellection. The former must retain the individuality that goes with embodiment; the latter does not. For Aristotle, the highest good is the activity of the Prime Unmoved Mover which we emulate in theoretical activity. For Plotinus, the highest good is the Idea of the Good itself, one and absolutely simple. Embodied intellection is two removes from this, not one. Intellection is good not because it is intellection; it is good because of its proximity to the first principle of all. ${ }^{38}$ The absolute simplicity of that first principle makes it seem obvious to Plotinus that paramount proximity to it could not be embodied intellection, which goes along with, that is, is inseparable from, embodied desire.

It is perhaps now easier to see why, though Plotinus thinks that in ethics the Stoics are 'on the right track', he ultimately separates himself from them. ${ }^{39}$ For the Stoics, the fact that virtue is sufficient for happiness does not preclude the fact that we pursue 'primary things' by

\footnotetext{
${ }^{35}$ See 1.1.2.25-30; 4.7.13, 4.8.8; 6.7.5.26-9.

${ }^{36}$ See De Anima 3.4.429a15.

${ }^{37}$ Cf. Armstrong (1941), 39-41.

${ }^{38}$ Cp. 1.4.4.19-20 with 1.4.3.37-40 on the distinction between the Good and the goodness in something. This distinction entails that if something is good, it is because it partakes of the Good, not because of what it is in itself.

${ }^{39}$ 1.4.2.31-55. Cf. Bussanich (1992), 154-6, on the difference between Plotinian and Stoic ethics.
} 
nature. ${ }^{40}$ For example, we pursue health by nature, even though this is, strictly speaking, a 'preferred indifferent', meaning that it is not absolutely necessary for virtue. ${ }^{41}$ For Plotinus, to pursue these 'primary things' is to acknowledge implicitly that the good to be achieved is inextricable from a personal or idiosyncratic good. ${ }^{42}$ Moreover, if reason is to be put in the service of acquiring these primary things, then it is the attainment of them and not the identification with reason that is ideal. ${ }^{43}$ If, however, the Stoics claim instead that reason is valuable for its own sake, then they are obliged to tell us why this is so. Since non-instrumental reason is precisely unconcerned with the idiosyncratic, they are obliged to explain why identification with its operation is desirable for anyone. They cannot do so, Plotinus thinks, because for them reason is necessarily embodied. If following reason, that is, the necessary operation of nature, is all that there is to happiness, then even a stone can be happy when it falls. If the perfect operation (teleiosis) of reason independent of primary things is the goal, why is this so $?^{44}$

Plotinus identifies 'happiness' with 'blessedness', not, like the Epicureans and Stoics, because both terms express or are equivalent to 'absence of disturbance', but because both terms are equivalent to 'identification with intellect', that is, with intellectual activity. ${ }^{45}$

It is obvious from what has been said elsewhere that a human being has a perfect life by having not only a soul capable of sense-perception but also one capable of reasoning and true intellection. But is he different from this when he has it? No, he is not entirely a human being if

\footnotetext{
${ }^{40}$ D. L., 7.87-9; Cicero, de finibus 3.16-18; 5.17-20; Epictetus, Discourses 2.6.9 = SVF 3.191.

${ }^{41}$ On indifferent generally see D. L., 7.101-05; Stobaeus, 2.79.18-80.13; 82.20-1.

${ }^{42}$ As D. L., 7.89, notes, Cleanthes claimed that 'following nature' only meant following 'common nature' not one's individual nature. But this was specifically rejected by Chrysippus, whose view became the standard Stoic position and the one that Plotinus is addressing. Cf. 2.9.9.74-6: 'For one must not look to what is in the interests of (katathumios) of each individual, but to [what is in the interest of] the whole universe'.

${ }^{43}$ 1.4.2.38-43. Cf. 5.9.1.11-15 and 6.8.2.36-7 where Plotinus suggests that all practical reason is tainted because of its instrumentality. Hence, its use cannot be 'up to us' (eph' hêmin). The same criticism would apply to Aristotle.

${ }^{44}$ See D. L., $7.90=$ SVF 3.190 for this characterization of the Stoic goal.

${ }^{45}$ See 1.4.4 with 1.6.7.33 and 5.1.4.14-19.
} 
he does not have this, whether in potency or in actuality (happiness being the actuality, we maintain). But shall we say that he who has this kind of perfect life has this as a part of himself? Is it not the case rather than other human beings have it as a part by having it potentially, whereas the happy human being who is this life in actuality and has transformed himself in becoming identical with it, is this. The other things are then just what he wears, which one could not call a part of him since he wears them without wanting to. It would be a part of him if it were joined to him according to an act of will. What then is the good for him? He himself is the good for himself which he has. ${ }^{46}$

This revealing passage lays out a number of possibilities. A human being (anthrōpos) is a living soul-body composite possessing a hierarchy of psychical powers, the highest of which is the operation of intellect. ${ }^{47}$ But a person or self is distinguishable from the composite human being or from any one of these powers. In order to get a feel for what this distinction amounts to, we can start simply with the obvious phenomenological distinction that everyone makes between themselves and their possessions. It is not now important that this distinction is sometimes difficult or even impossible to make ("is my brain "me" or "mine"'?); what is crucial is that we do inevitably make it whenever we have to make important decisions about our own futures. For example, one would presumably give up one's own finger unhesitatingly to save one's life, whereas one might at least hesitate to agree to a brain transplant with the same goal in mind.

Once we recognize our capacity for making the relevant distinction, we can then move on to the distinction between oneself and oneself as the subject of various psychical states, like desires, beliefs, emotions, and so on. It works like this. I discover in myself a desire for something and, as a rational living being, I can either endorse that desire or I can resist it, indeed, I can seek to extirpate it. Curiously, the mere possibility of my resisting my own desires at the very moment that I have them and recognize them as my own impels me to reflect on how I can want something different from what I want. ${ }^{48}$ It further impels me to wonder that if I am a 'divided self'-divided between the subject of the 'first order' desire and the 'second order' desire-which 'self' is me and which self is mine? The answer to the question is all important

\footnotetext{
${ }^{46} 1.4 .4 .6-19$.

${ }^{47}$ Owing to intellect, all other cognitive powers are present to human beings.

${ }^{48}$ The subject of resistance is the 'human being within the human being' that Plato speaks of at Republic 589A7.
} 
Journal of Ancient Philosophy Vol. VI 2012 Issue 1

for deciding whether we shall privilege the first or second order desire when these are in conflict and cannot possibly both be satisfied. Shall I classify my disinclination to act on the grounds that these belong to me but they are not me or expressive of my identity? Or shall I suppress my desires, which are mere possessions, in favor of what is good for me as determined by my second order desires?

For reasons already canvassed, Plotinus has no doubts that the ideal person is more closely to be identified with the subject of the second order desire than with the subject of the first. So, self transformation amounts to a detachment from identification with the subject of the first order desires in favor of identification with the subject of the second. If we were to stop here, we would essentially have, I believe, the Aristotelian and the Stoic positions. But for Plotinus, and according to Plotinus for Plato, the subject of second order desires is still and embodied subject. Hence, it is a subject of embodied desires. ${ }^{49}$ The satisfaction of the desire to live in contemplation or of the desire to follow the dictates of reason does not amount to happiness because neither of these is constituted by unqualified identification with intellect.

It is a nice question whether such identification is possible for an embodied human being. I suspect that Plotinus' view is that the ideal is for embodied individuals an asymptote, as it were, to which one can be either closer or father away but which cannot be achieved unqualifiedly in the embodied state. ${ }^{50}$ For one who has achieved the apex of embodied identification, the desires of his embodied self seem to him to be almost as if they were those of another. $^{51}$ That is why Plotinus insists,

But the real longing (ephesis) [of the soul] is for that which is better than itself. When that is present, it is fulfilled and at rest, and this is the truly willed (boulētos) life. ${ }^{52}$

Two crucial terms in this passage are 'longing' (ephesis) and 'willed' (boulētos). The first term is generally distinguished by Plotinus from the generic term for desire, orexis. The latter

\footnotetext{
${ }^{49}$ Cf. Republic 580D8.

${ }^{50}$ Plotinus is right, I believe, in thinking that this is Plato's view as well.

${ }^{51}$ Cf. 6.4.15.35-8 : 'whoever enslaves this mob [of bodily appetites], lives and runs back to the human being that he once was, lives according to that human being and is him and gives to that body as if giving to something other than himself'.

52 1.4.6.17-19.
} 
term represents the essential feature of soul, that is, its motion in the direction of specific goal achievement originating in embodiment. But as we have seen, human beings alone are 'suspended' from our intellects and so ideally identified with them. The term ephesis indicates paradigmatically intellect's orientation to the Good. ${ }^{53}$ Intellect eternally longs for and eternally attains the Good in contemplation of it. Derivatively, ephesis indicates a desire for something only insofar as it is good. So, one can have orexis for, say, physical pleasure, but this orexis is also an ephesis only if one were to regard physical pleasure as the Good itself. Since nothing but the Good is the Good itself, the only true ephesis, 'the real ephesis [of the soul]', is for the Good.

The other term, boulètos, is from the noun boulessis, which is close to being synonymous with ephesis, but also with the activity of intellect itself. It is self-conscious ephesis, that is, selfconscious longing for the Good. ${ }^{54}$ When intellect recognizes the Good, it 'proposes' it to the will, which immediately longs for it. That is why in reality there is no difference between intellection, longing, and achievement of what is longed for. We distinguish orexis from ephesis because the former may not be self-conscious that what it really desires is the Good; the latter is that selfconscious desire. As self-conscious, it is a will for the Good alone. This willing the Good alone is paradigmatically in intellect and only derivatively in embodied human beings. The transition point between the Aristotelian and Stoic position, on the one hand, and Plotinus' position, on the other, is from a self-conscious desire (orexis) for $\mathrm{x}$ as good to a longing (ephesis) for the Good itself.

The longing for the Good itself and the achievement of this longing in contemplation of all that is intelligible is for us already a reality in our undescended intellects. We, however, do not notice this, as Plotinus insists. ${ }^{55}$ The awareness (antilepsis) of its activity by us would amount to identification with it. ${ }^{56}$ That would be perfect happiness. So, perfect happiness

\footnotetext{
${ }^{53}$ See 1.6.7.3 and esp. 6.7.21.1-6; 6.7.27.24-7: 'But now, if this [that something is good because it participates in the Good] is correct, the movement upward has the Good as residing in a particular nature, and it is not longing that makes it Good, but there is longing because it is Good...'.

${ }^{54}$ See 6.8.6.32-8.

${ }^{55}$ 1.4.10.1.

${ }^{56}$ 1.4.9.28-30.
} 
Journal of Ancient Philosophy Vol. VI 2012 Issue 1

requires the elimination of the idiosyncratic, the background noise of embodiment. But this noise, it would seem, is comprised of the very stuff out of which a satisfactory human life is made. Its elimination would evidently obliterate the gap between fulfillment of one's nature and satisfaction, but at what cost?

If some people were to say that a human being in this state is not even alive, we shall insist that he is alive, but that his happiness, like his life, escapes them. If they are not persuaded, we will ask them to begin with the living human being or the excellent person (spoudaios), and thus to ask if he is happy, and not having diminished his life, to seek to discover if he is living well, and, without removing his humanity, to seek to discover human happiness, and while conceding that the excellent person turns inward, not to seek for his happiness in external activities nor in general to seek the object of his will in externals. For if one were to say that externals were willed and that the excellent person willed these, in this way one would be denying that happiness exists. ${ }^{57}$

The central point of this passage is that the critic, before dismissing the present account of happiness as inhuman, must look at the actual life of the excellent person (spoudaios). ${ }^{58}$ In the interstice between disembodiment and a life of embodied desire, his happiness is to be found.

The principal characteristic of the life of the excellent person is that he is 'self-sufficient' (autarkēs). ${ }^{59}$ The excellent person is happy because he is self-sufficient or perhaps his excellence consists in his self-sufficiency. ${ }^{60}$ We recall that Aristotle makes self-sufficiency a hallmark of

\footnotetext{
${ }^{57} 1.4 \cdot 11.1-12$.

${ }^{58}$ Some commentators have suggested that the critic here is a Stoic. See McGroarty (2006), 161-5, for references. As McGroarty argues, this seems unlikely. The main reason I believe for this is that the Stoic sage was not in the minds of Stoics someone who actually exists. He was an ideal. Socrates was often cited as perhaps one of the only authentic sages who ever existed. By contrast, the Plotinian virtuous person is someone who is real and whose life can be examined to see if it is happy. There has to be such a person to counter the objection that such a person would not even be alive.

${ }^{59}$ See 1.4.4.23-5; 1.4.5.23-4.

${ }^{60}$ See Schniewind (2003), 120-2, who argues that the passage 1.4.4.23-5 should be understood to say that being spoudaios is what makes one's life self-sufficient, rather than the other way around. In the editio maior of Henry and Schwyzer, the text seems to support this. But in the later editio minor, and under the influence of Beutler and Harder, Henry and Schwyzer print a text that is slightly different and seems to support the interpretation that it is self-sufficiency that makes the spoudaios. But as Schniewind herself says, on her interpretation being a spoudaios is a necessary and sufficient condition for having a selfsufficient life. If this is so, then being spoudaios and having a self-sufficient life are probably meant to be understood as being extensionally equivalent.
} 
Journal of Ancient Philosophy Vol. VI 2012 Issue 1

happiness. But we also saw that for Aristotle this self-sufficiency falls short of blessedness. Plotinus, identifying happiness with blessedness, alters the meaning of 'self-sufficient' in order to identify it with the interior life of the excellent person. This interiority or self-sufficiency is the obverse of attachment to the objects of first order embodied desires. Interiority is happiness because the longing for the Good for one who is ideally an intellect is satisfied by cognitive identification with all that is intelligible. If this is not unqualifiedly possible for the embodied human being, it does at least seem possible that one should have a second order desire that amounts to a profound indifference to the satisfaction of first order desires. Understanding that the good for an intellect is contemplation of all that the One is means that the will is oriented to one thing only, whatever transient desires may turn up. ${ }^{61}$

It hardly needs adding that the life of interiority or detachment does not preclude the practice of ordinary virtue. ${ }^{62}$ What is plainly precluded, however, is the exposure of the excellent person to ill fortune. Such a person is 'confident that evil cannot touch him because he has in a way become an entirely different human being, ${ }^{63}$ As this different human being, he looks upon his embodied desires almost as if they were those of another. Precisely for this reason, the desires of others are considered by him to be no less real or deserving of satisfaction than his own. ${ }^{64}$ When he satisfies these, he does so because not to satisfy them would be an impediment to interiority. I mean, for example, that a decision not to assist someone in genuine need when the opportunity arises could only arise from a contrary desire. If that contrary desire is one's own,

\footnotetext{
${ }^{61}$ In 1.3., 'On Dialectic', Plotinus argues that the practice of dialectic as described by Plato is essential to moral improvement. He frequently describes this practice as a sort of purification. It is essential because, though all desire the good, one must first know what that is. The goal of dialectic is to know what the Good is virtually, that is, the intelligible world. In knowing that, one longs for it, and interiority is a state of willing the achievement of that longing. The language of purification is applied here especially to desire which is transmuted into the resultant purified longing for the Good.

${ }^{62}$ See 1.3.6.14-17. Cf. Remes (2006), 7-13. The comparison of Plotinus' account of detachment and the practice of virtue entailed by it with Buddhist doctrine is not inapposite. It cannot, unfortunately, be pursued here.

${ }^{63}$ 1.4.15.13-14. Cf. Bodéüs (1983), 256-64, which is largely concerned with this passage.

${ }^{64}$ Cf. 1.4.15.21-5: 'A human being like this will not be unfriendly or hardhearted; for he is like this about himself and with things that concern him. Then, giving to his friends what he gives to himself, he would be an especially intellectual (meta tou noun echein) friend'.Cf. Epictetus, Discourses 1.19.11-15; 2.22.15$16 ; 2.22 .18-21$.
} 
Journal of Ancient Philosophy Vol. VI 2012 Issue 1

then most likely one has already declined from the interior state. Indeed, Plotinus seems to go further when, arguing against unnamed 'Gnostics', he claims that one of their principal flaws is that they have no doctrine of virtue: 'but those who have no share of virtue would not at all be moved to the intelligible world, ${ }^{65}$

The desires from which the excellent person is detached are bodily in the precise sense that they require a body for their existence, but they are not desires of the body over against the soul. They are desires of the embodied person, composed of body and soul. These are the desires the satisfaction of which the opponents of both Aristotle and the Stoics claimed were necessary for happiness. ${ }^{66}$ Plotinus concedes their existence, even in the excellent person-how could he not? - but at the same time refuses to integrate their satisfaction into the happy life. In this regard, one may compare the Plotinian excellent person vis-à-vis the ordinary human being with the adult vís-à-vís the child he once was. Childish desires are understandable in a child; they are unworthy of an adult. Similarly, the desires of ordinary people are understandable for ordinary people, those who identify themselves with the adventitious subjects of embodied desires. There is no predicting or guaranteeing that an ordinary person will reflect on whether or not that identification is correct any more than there is that the physical adult will outgrow his childish desires. If, however, such a person begins to undertake a process of philosophical reflection on what will genuinely make him happy, the very process of reflection may lead him to the realization that the power of reflecting that he is currently employing is available to him only if he is really something other than he had supposed. The essential self-reflexivity of thinking is not a by-product of biological development. But without having access to that, a critical examination of whether, say, the life of pleasure or the life of virtue is to be preferred would be impossible. With that critical examination, perhaps under Aristotelian auspices, one begins to be in a position

\footnotetext{
${ }^{65}$ 2.9.15.26ff. Plotinus in this chapter seems to assume that because the Gnostics do not have an explicit doctrine of virtue, they are indifferent to it in their lives. This may be an unwarranted assumption, but then it probably never occurred to Plotinus that a serious commitment to philosophy would not automatically affect one's way of being in the world.

${ }^{66}$ Cf. 1.4.16.9: 'nor is it possible to live happily in the common life' (en tō koinō). That is, the happy life is not to be found in a blend of bodily and psychic goods. Cf. Republic 558D11-E3 with 581E3-4 where Plato acknowledges the 'necessary desires' of the embodied person, those that nature requires us to satisfy.
} 
Journal of Ancient Philosophy Vol. VI 2012 Issue 1

to see that one's good is the good for an intellect. And the only good for an intellect is intellection of all that the Good is. And what the intellect identifies as the Good, the will cannot but long for. The self-consciousness of that longing is all that is required for excellence, or genuine maturity.

Bibliography

Armstrong, Hilary (1941), The Architecture of the Intelligible Universe in the Philosophy of Plotinus, Cambridge, Cambridge University Press.

Bodéüs, Richard (1983), 'L'autre homme de Plotin', Phronesis 23, 256-64.

Bussanich, John (1992), 'The Invulnerability of Goodness: The Ethical and Psychological Theory of Plotinus', Proceedings of the Boston Area Colloquium in Ancient Philosophy 6, 15184.

Gerson, Lloyd P. (1996), 'Socrates' Absolutist Prohibition of Wrongdoing', in Wisdom, Ignorance, and Virtue. New Essays in Socratic Studies. Edited by Mark McPherran, Edmonton: Academic Printing and Publishing, 1-13

Gerson, Lloyd P. (2003), Knowing Persons, Oxford: Oxford University Press.

McGroarty, Kieran (2006), Plotinus on Happiness. A Commentary on Ennead 1.4, Oxford: Oxford University Press.

Remes Pauliina (2006), 'Plotinus's Ethics of Disinterested Interest', Journal of the History of Philosophy 44, 1-23.

Schniewind, Alexandrine (2003), L'éthique du sage chez Plotin. Le paradigm du spoudaios, Paris: Vrin. 